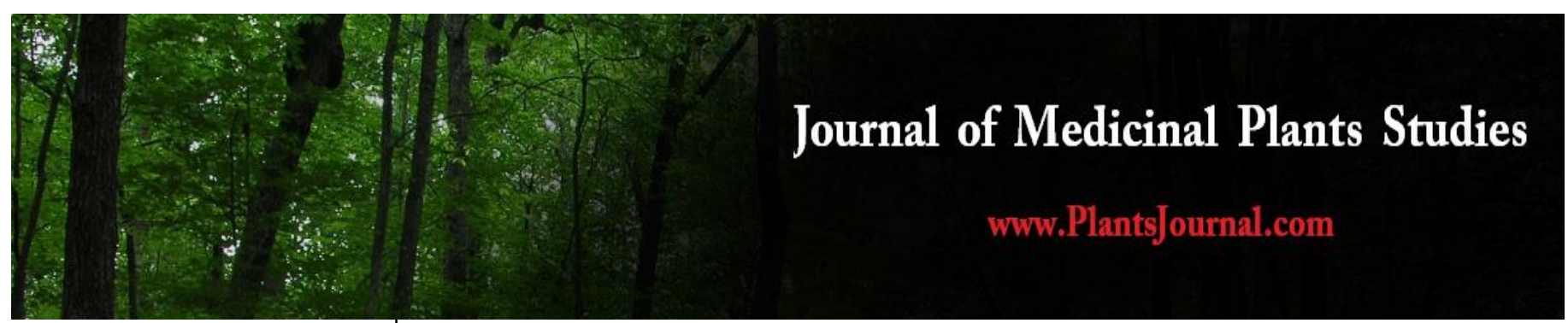

ISSN (E): 2320-3862

ISSN (P): 2394-0530

www.plantsjournal.com

JMPS 2021; 9(4): 01-03

(C) 2021 JMPS

Received: 01-05-2021

Accepted: 03-06-2021

Nikita Saxena

PG Scholar, Sri Jayendra

Saraswathi Ayurveda College and

Hospital, Department of Ayurveda of Sri Chandrasekharendra

Saraswathi Vishwamahavidyalaya,

Enathur, Kanchipuram

Tamil Nadu, India

Anita Patel

Associate Professor, Sri Jayendra Saraswathi Ayurveda College and

Hospital, Department of Ayurveda of Sri Chandrasekharendra

Saraswathi Vishwamahavidyalaya,

Enathur, Kanchipuram,

Tamil Nadu, India
Corresponding Author:

Nikita Saxena

PG Scholar, Sri Jayendra

Saraswathi Ayurveda College and

Hospital, Department of Ayurveda of Sri Chandrasekharendra

Saraswathi Vishwamahavidyalava,

Enathur, Kanchipuram,

Tamil Nadu, India

\section{Ayurveda management of varicose eczema (Vicharchika): A case report}

\section{Nikita Saxena and Anita Patel}

DOI: https://doi.org/10.22271/plants.2021.v9.i4a.1304

\section{Abstract}

Skin diseases are the most common health problems worldwide. Varicose eczema is such an ailment which causes Psychological, social and financial burden on patient and their families. Varicose eczema is the condition usually present secondary to varicosity of superficial veins. From Ayurveda view Vicharchika is a type of Kshudra kustha often encounted by Ayurvedic Dermatologists characterized symptoms like kandu (Itching) Srava (discharge) Pidika (vesicle) and Shyav Varna (discoloration). A 70 year old female patient reported with complain of itching, pain, burning sensation, discharge in the lateral and medial side of right leg and discoloration. The main line of treatment of Vicharchika in Ayurveda is Shod Hana Virechan (therapeutic purgation) Shaman Aushadhi (Internal medication) and raktamokshana, external treatment leech therapy. After the treatment all signs and symptoms have reduced significantly.

Keywords: Jalaukavacharana, Virechana karma, pitta dosh, varicose eczema, Vicharchika

\section{Introduction}

In Vicharchika, it is a skin ailment wherein eruption over the skin appear with dark pigmentation, itching and with profuse discharge. Pitta is the main dosha responsible for origin of vicharchika. In Ayurveda Pitta manifests in the skin and produces heating toxins called "Ama".these toxins seep into body tissues contaminating them on a deep level and resulting in Vicharchika ${ }^{[1-4]}$.

Varicose Eczema, which is a complication of varicose vein. Manifests as oedema, hyperpigmentation, venous dermatitis, chronic cellulitis, oozy discharge from lesions and ulceration.

Varicose eczema is caused when pressure increase in the veins running under the skin in the deep muscles of the legs. The raised pressure is due to leaky valves in the veins. When the valves are not working well, it is difficult for the blood to flow back up the legs against gravity. The increased pressure in the veins makes them leak. Fluid and blood cells leak out of the veins and under the skin. Over time affected skin becomes harder and discoloured, because skin becomes with eczema is scaly and can become broken. And it is more prone to developing ulcers ${ }^{[5]}$.

\section{Case Report \\ The Patient}

A 70 years old female patient reported in opd of Shri jayendra Saraswathi Ayurved College Nazarthpetthai complains of chronic Itching, burning sensation pain, discharge, discoloration in right lower medial and lateral side of right lower limb since 6 months.

\section{History of the illness}

A Patient known case of varicose vein since few years back but she was Asymptomatic. She noticed Itching, burning, discoloration near right ankle and foot in since last month.

On examination we found oozy brownish skin lesions with scaling. No past history of any disease, no any history of Hypertension, Diabetic mellitus, tuberculosis, anaemia, cardiac disease and any other illness. CBC, Blood sugar level BT CT, serum creatinine and lipid profile were normal. 


\section{The treatment}

\begin{tabular}{|c|c|c|}
\hline Manibhadra Leham ${ }^{[6]}$ & 10 gm before sleep & $\begin{array}{l}\text { Mridu Virechanam for } 15 \text { days follow up. } \\
\text { It is jaggery based medicinal preparation. } \\
\text { It has natural healing property on skin lesions. } \\
\text { It is used as Mridu Virechanam in skin diseases. }\end{array}$ \\
\hline Avipathy Choornam ${ }^{[7]}$ & $5 \mathrm{gm}$ before sleep & $\begin{array}{l}\text { Mridu Virechanam for next } 15 \text { days follow up. } \\
\text { It is purgation therapy for balancing Pitta. }\end{array}$ \\
\hline Aragwadharishtam ${ }^{[8]}$ & $15 \mathrm{ml}$ twice in a day & $\begin{array}{l}\text { Mridu Virechanam for next } 15 \text { days follow up. } \\
\text { It has mild Laxative property which helps healing skin lesions. }\end{array}$ \\
\hline Khadiraristha ${ }^{[9]}$ & $\begin{array}{l}15 \mathrm{ml} \text { Twice in a } \\
\text { day }\end{array}$ & $\begin{array}{l}\text { It helps in alleviating symptoms like itching, discoloration of skin. } \\
\text { It has anti-inflammatory, anti-microbial property which is used as blood purifier } \\
\text { as well as mild laxative in skin diseases like varicose eczema. }\end{array}$ \\
\hline $\begin{array}{l}\text { Nimbamritadi Panchatiktam } \\
\text { Kwatham tablet }{ }^{[10]}\end{array}$ & 2 tab at 6 am & $\begin{array}{l}\text { Given as shaman aushadi for } 20 \text { days. } \\
\text { It balances pitta and kapha. } \\
\text { It has healing property. }\end{array}$ \\
\hline $\begin{array}{c}\text { Aragwadhadi kashayam tablet }{ }^{[11]} \\
+ \\
\text { Kaishor guggul }^{[12]}\end{array}$ & 1 tab at night & $\begin{array}{c}\text { Given as shamana aushadi for } 20 \text { days follow up. } \\
\text { Aragwadhadi k tab has anti-inflammatory, anti-microbial properties which cleans } \\
\text { skin infection and reduces kapha dosha of skin. } \\
\text { Kaishor guggul is an amazing blood purifier and it has anti-inflammatory } \\
\text { properties.it cleans extra Pitta from system. }\end{array}$ \\
\hline Psorakot & $1 \mathrm{TDS}$ & It reduces inflammation in Psoriasis condition as well as Varicose eczema. \\
\hline $\begin{array}{l}\text { Triphala churnam }{ }^{[13]} \\
\text { Durvadi coconut oil }^{[14]} \\
\text { Tiktakam Kashayam }^{[15]}\end{array}$ & \begin{tabular}{|}
10 gm for washing \\
of wounds. \\
For local application \\
$15 \mathrm{ml}$ at $6 \mathrm{am}$
\end{tabular} & $\begin{array}{l}\text { Triphala churana has anti septic and anti-microbial properties. } \\
\text { Durvadi coconut oil has anti-viral and good healing properties. } \\
\text { It has anti allergic property and it maintained the balance of pitta dosha in body. }\end{array}$ \\
\hline
\end{tabular}

\section{Poorva Karmam (Pre-operative procedure)}

Non-poisonous leeches were identified ${ }^{[16]}$, It also include Leech disinfection, before use leeches were smeared with a paste of mustard and turmeric, which acts as a disinfectant and increase their appetite and blood sucking ability. Leeches are kept on fresh water jar. Patients BT and CT verified.

\section{Pradhana karmam (Main procedure)}

The area to which leeches were to be applied was thoroughly cleaned with sterile water and dried with cotton, the leech was taken from its jar and its mouth placed over the lesions. Leeches only suck impure blood. While sucking the blood it shows the hoop of the horse by raising its neck region. Remove the leeches gently after sucking of pure blood. Symptoms such as pricking pain and mild itching when they suck pure blood, the leeches were being gently removed by sprinkling turmeric around its mouth.

\section{Pashchyat Karmam (Post-operative procedure)}

After the removal of the leeches, blood was to be allowed to flow from the wound for few minutes, wound was cleaned with antiseptic solution, after that Shatadhauta ghritam ${ }^{[17]}$ was applied to promote healing. The wound area was also lightly bandaged for 6 to 12 hours.

After that, the same procedure was repeated for 6 weeks. Patient was examined weekly during treatment. Pain in lesions, itching, and oozing discharge reduced after 4 sitting of leech therapy and Shamana aushadhis.

\section{Constituents of Leech Saliva}

- Hirudin: Hirudin (mainly from leech) having approximately three times more anti-thrombin activity Than pseudohirudin (maily from leech whole body).

- Calin: It also prevents the blood coagulation.

- Destabilise: It completely blocks the spontaneous aggregation of human platelet.

- Hyaluronidase: It's "spreading factors" that ensures the other active substances which are active at the bitten Areas can be spread. Eglin restrains digestive proteases, bdellin is a plasma hindrance.

- Anti-thrombin, antitrypsin and antichymotripsin:
High antithrombine activity is maintained in starved leeches. An anaesthetic substances leads to pain insentivity (analgesic) when sucking such pain killer Chemical, which stops feeling of bite.

- Hementin and orgelase: Have a hyperaemistic effect but it is remained in limited leeches.

- Piavit: It has protective antithrombotic effects. The salivary glands of leeches also produce comucopia of other pharmacologically active substances including an antihistamic, protease and possibly, an anaesthetic and antibiotic.

\section{Assessment Criteria}

Patient was examined weekly during the treatment. Assessment was done on the basis of sign and symptoms of disease varicose eczema (Vicharchika).

\section{Follow Up}

The follow -up was carried out up to 6 months from the end of the treatment with intervals of 15 days to rule out progression of the disease and adverse reactions.

\section{Discussion}

Vicharchika is a type of kshudra kustha mainly caused by Virudhahara ${ }^{[18]}$ and Rakta dhatu dushti. Shodhana is must appropriate method. Virechana karma to eliminate vitiated Pitta and Rakta Dosha and Vata Anulomana (Passage of flatus) was planned. In the course of treatment Deepana Pachana dravyas were administered for correction of Agni.

Shodhana is considered as the most appropriate method. Jalaukavacharanam is considered to be more scientific and safe method. The anti-inflammatory substances present in leech saliva, are responsible for reduction of redness and oozing of lesions. It also induces granulation tissue formation which is responsible for reduction of thickness in eczema. Leech saliva contains Hylaurinadase which has antibiotic properties and that may be responsible for the reduction of oozing in varicose eczema. The saliva of leech contain a variety of substances such as Hirudin, Hylaurinadase, Histamine like vasodilators, collagenase etc. 


\section{Conclusion}

Virechanakarma, Jalaukavacharanam karma provides relief in the symptoms of Vicharchika like Kandu, Pidika, and Daha etc. And internal medication along with local care of eczematous part resulted in the reduction of signs and symptoms of Vicharchika (Varicose eczema) like pain, oozing discharge, discoloration, burning and itching. During the follow up period there was no aggravation in the eczema, was completely cured after 50 days. The treatment employed was purely based on principles of Ayurveda. The condition of the patient improved remarkably.

\section{References}

1. Kaviraj Dr. Ambikadutt Shastri, editor. Sushruta Samhita Nidansthana 6, 13-15, Varanasi Chaukhamba Orientalia 2008, 322.

2. Kaviraj Dr. Ambikadutt Shashtri, editor. Sushruta Samhita Sutrastana Chapter 13, Varanasi Chaukhamba Orientalia 2008 publication.

3. Vaidya Yadavji Trikamji Acharya, editor. Sushruta Samhita Nidansthan 6, Shlok 13, Varanasi Chaukhamba Subharti Publication 285.

4. Prof. Srikantha Murthy KR, editor. Ashtang Hridayam Nidansthan 14,33-36, Chowkhamba Krishnadas Academy, Varanasi 142.

5. Prof Srikantha Murthy KR, editor. Ashtang Hridayam Nidansthan 14,37-38, Chaukhamba Krishnadas Academy, Varanasi 143.

6. Prof Srikantha Murthy KR, editor, Ashtang Hridayam Chikitsa Sthan 19,31-32, Chowkhamba Krishna das Academy, Varanasi 477.

7. Prof Srikantha Murthy KR, editor. Ashtang Hridayam Shlok 2-7, Chapter 19, Chowkhamba Krishnadas Academy, Varanasi 472.

8. Dr. Nishteshwar K, Dr. Vidhyanath R, editor. Shahastra Yogyam Churna Prakranam, Chaukhambha Sanskrit Publication, Varanasi 200.

9. Sreekumar $\mathrm{T}$, editor. Ashtang Hridayam $2^{\text {nd }}$ edition Sutrasthan 15, Shlok 17, Harishree Hospital Publication, Kerala 381.

10. Dr. smt Shailja Shrivastava, editor. Sharangdhar Samhita 10 Madhya khand, 60-64, Chaukhamba orientalia, Varanasi 252.

11. Prof Srikantha Murthy KR, editor. Ashtang Hridayam Chikitsa Sthan 21, 57-60, Chowkhamba Krishna das Academy, Varanasi 508.

12. Sreekumar $T$, editor. Ashtang Hridayam $2^{\text {nd }}$ edition Sutrasthan 15, shlok 17, Harishree Hospital Publication, Kerala 381.

13. Dr. smt. Shailja Shrivastava, editor. Sharangdhar Samhita 7 Madhya Khand, 70-81, Chaukhamba orientalia, Varanasi 204.

14. Dr, smt. Shailja Shrivastava, editor. Sharangdhar Samhita 6 Madhya khand, 9-11, Chaukhamba orientalia, Varanasi 174.

15. Dr. Niteshwar K, Dr. Vidhyanath R, editor. Sahasra Yogam 3 tailam prakranam, Chaukhamba Sanskrit Publication, Varanasi 149.

16. Prof Srikantha Murthy KR, editor. Ashtang Hridayam Chikitsa Sthan 19, 2-7, Chowkhamba Krishnadas Academy, Varanasi 472.

17. Kaviraj Dr. Ambikadutt Shastri, editor. Sushrut Samhita Sutrasthan 13, shlok 23, Chaukhamba Sanskrit Sansthan, Varanasi 60.

18. Acharya Mishra SN, editor. Abinava Bhaishajyakalpana
Vijana $4^{\text {th }}$ edition, 1993, Chaukhamba Subharti Prakashan, Varanasi 301. 